\title{
Family Firms Can Optimize Women's Strengths
}

\section{Kimberly Eddleston (Northeastern University)}

KEYWORDS: Management, Family Business, Women.

Family businesses are far ahead of non-family businesses in letting women help shape important decisions, but both the family firms and the women themselves must make some changes in order to optimize their strengths. In this interview with familybusiness.org Editor Kimberly Eddleston, Rania Labaki, Director of the EDHEC Family Business ResearchCenter(https://www.edhec.edu/en/familybusiness-centre), discusses how women often juggle many business and family roles, and typically shun the idea of power because they associate it with dictators and manipulation. Family businesses also make the mistake of putting women into important roles without giving them the training they need to do it well. Labaki calls for women and businesses to embrace a new way of managing, combining the best of both worlds: traditionally male assertiveness with traditionally female empathy and decision-making skills. 